\title{
Border Cinema
}




\section{Global Media and Race}

Series Editor: Frederick Luis Aldama, The Ohio State University

Global Media and Race is a series focused on scholarly books that examine race and global media culture. Titles focus on constructions of race in media, including digital platforms, webisodes, multilingual media, mobile media, vlogs, and other social media, film, radio, and television. The series considers how race-and intersectional identities generally-is constructed in front of the camera and behind, attending to issues of representation and consumption as well as the making of racialized and antiracist media phenomena from script to production and policy.

Monica Hanna and Rebecca A. Sheehan, eds., Border Cinema: Reimagining Identity through Aesthetics 


\title{
Border Cinema
}

Reimagining Identity through Aesthetics

\author{
EDITED BY MONICA HANNA \\ AND REBECCA A. SHEEHAN
}

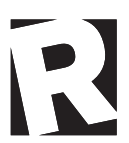

Rutgers University Press

New Brunswick, Camden, and Newark, New Jersey, and London 
Library of Congress Cataloging-in-Publication Data

Names: Hanna, Monica, editor of compilation.| Sheehan, Rebecca A., 1979- editor of compilation.

Title: Border cinema : reimagining identity through aesthetics / edited by Monica Hanna and Rebecca A. Sheehan.

Description: New Brunswick, N.J. : Rutgers University Press, [2019] | Series:

Global media and race Includes bibliographical references and index.

Identifiers: LCCN 2018027678| ISBN 9781978803169 (cloth) | ISBN 9781978803152 (pbk.)

Subjects: LCSH: Boundaries in motion pictures. | Identity (Psychology) in motion pictures. | Motion pictures-Aesthetics. | Digital cinematography.

Classification: LCC PNi995.9.B67 B665 2019| DDC 791.43-dc23

LC record available at https://lccn.loc.gov/2018027678

A British Cataloging-in-Publication record for this book is available from the British Library.

This collection copyright ( ${ }_{2019}$ by Rutgers, The State University of New Jersey

Individual chapters copyright $\left.{ }^{(}\right) 2019$ in the names of their authors

All rights reserved

No part of this book may be reproduced or utilized in any form or by any means, electronic or mechanical, or by any information storage and retrieval system, without written permission from the publisher. Please contact Rutgers University Press, 106 Somerset Street, New Brunswick, NJ 0890I. The only exception to this prohibition is "fair use" as defined by U.S. copyright law.

$\Theta$ The paper used in this publication meets the requirements of the American National Standard for Information Sciences-Permanence of Paper for Printed Library Materials, ANSI Z39.48-1992.

www.rutgersuniversitypress.org

Manufactured in the United States of America 